\title{
Students' Result of Learning at Chemistry Department through Assessment of, for, and as Learning Implementation
}

\author{
Muchlis
}

Graduate School, Universitas Negeri Malang, Indonesia, muchlis@unesa.ac.id

\section{Suhadi Ibnu}

Prof., Graduate School, Universitas Negeri Malang, Indonesia, suhadi.ibnu.fmipa@um.ac.id

\section{Subandi}

Prof.,Graduate School, Universitas Negeri Malang, Indonesia, subandi.fmipa@um.ac.id

\section{Siti Marfuah}

Graduate School, Universitas Negeri Malang, Indonesia, siti.marfuah.fmipa@um.ac.id

\begin{abstract}
This paper focused on describing students' result of learning through assessment of, for and as learning implementations. The subjects of research were 35 students on Chemistry Department, Mathematics and Science Faculty of Surabaya State University, Indonesia. The technique of data collecting was paper test 1, 2 and 3, that it was used to measure students' result learning 1,2 and 3. The student was called mastery in learning if the student got value 55 or above. Student value was achieved from score achieved divided score maximum. Means' result of learning was found amount of all students value divided amount all of students. The range of the highest value is A and the range of the lowest value is E. Classical mastery was found from student amount of mastery in learning divided amount all of students. The research result showed that 1) percentage of student amount that's mastery in learning through assessment of, for, and as learning implementation successively were happened increasing 2) percentage of students amount for result of learning through assessment of, for and as learning implementation successively for value A were happened increasing and value $\mathrm{E}$ were happened decreased 3) means' result of learning through assessment of, for and as learning implementation were happened increasing respectively; and 4) based on Friedman test, students' result of learning through assessment of, for and as learning implementations were difference significantly.
\end{abstract}

Keywords: assessment as learning, assessment for learning, assessment of learning, result of learning, assessment

Citation: Muchlis, Ibnu, S., Subandi, \& Marfuah, S. (2020). Students' Result of Learning at Chemistry Department through Assessment of, for, and as Learning Implementation. International Journal of Instruction, 13(2), 165-178. https://doi.org/10.29333/iji.2020.13212a 


\section{INTRODUCTION}

Assessment is a part of learning (O'Farrell, 2009). Assessment is a process of information collection, and in the context of teaching, this information is typically used to examine and describe student performance (Enger \& Yager, 2009). We assess for the reasons 1) to determine that the intended learning outcomes of the course are being achieved, 2) to provide feedback to students on their learning, enabling them to improve their performance, 3) to motivate students to undertake appropriate work, 4) to support and guide learning, 5) to describe student achievement, informing decisions on progression and awards, 6) to demonstrate that appropriate standard are being maintained, and 7) to evaluate the effectiveness of teaching (O'Farrell, 2009). The assessment aims to find out students 'achievements, students' weaknesses and strengths, and strategies to improve student learning outcomes (Earl \& Giles, 2011).

Based on the approach to applying assessment, Earl (2003) divided the assessment into three approaches are assessment of learning, assessment for learning, and assessment of learning. Assessment of learning is also called assessment to summative evaluation, referring to formal checks on learning outcomes carried out by the teacher at the end of the teaching program (Earl \& Giles, 2011). Assessment of learning is also called assessment for summative purposes or summative assessment (Ussher \& Earl, 2010). The purpose of the Assessment of learning is summative evaluation, intended to certify learning and reports for parents of students and students about the progress of students in school, usually by marking student rankings relative to other students in their class (Earl, 2003).

As for assessment for learning refers to the assessment term for formative evaluation, namely a procedure in the formal and informal range carried out by the teacher as part of the normal process of teaching and learning and information obtained is used by teachers and students to modify and enhance learning and understanding (Earl \& Giles, 2011). Assessment for learning offers an alternative perspective on assessment in school, or simply term, assessment for learning shifts the emphasis from summative assessment to formative assessment, from making judgment to creating of descriptions that can be used in the service of the next stage of learning (Earl, 2003). At implementing assessment for learning, Heitink, et.al. (2016) explained that feedback was continually incorporated in this process to guide future learning. According to them, students play an important role, and are expected to engage in assessing their own and their peer's learning.

Hill (2008) described the role of assessment improve students' result of learning and teacher instruction in order to ensure students have reached their individual potential. Of course, the idea of assessment can help students in learning is not new, but assessment for learning is a one of the most powerful ways to improve student achievement (Wiliam, 2013). The results of Mehmood's study, also showed that students assessed by formative assessment had significantly higher scores than students who were not assessed by formative assessment (Mehmood et al., 2012). Similarly, according to Glasson (2008) that student achievement can be improved through assessment for learning. Other research results also show that the application of consistent assessment 
for learning will produce something extraordinary, if not something that has never happened, at least student achievement (Stiggins \& Chappuis, 2006).

The five main strategies associated with assessment for learning namely 1) clarifying learning intentions and criteria for success, 2) engineering effective classroom discussions and other learning tasks that elicit evidence of student understanding, 3) providing feedback that moves learners forward, 4) activating students as instructional resources for one another, 5) activating students as the owners of their learning (Team, 2014). Ideally, assessments for learning are those that 1 ) help the learners define where they are in meeting the objectives of a course; 2) identify what they need to do further; 3 ) prepare them to transfer their knowledge and skills to novel situations; 4) enable them to gain a deeper understanding of the material; and 5) provide them an opportunity to personalize their learning (Kulasegaram \& Rangachari, 2018).

Meanwhile, assessment as learning refers to assessment as students' metacognition skills and as a literacy (Earl \& Giles, 2011). Assessment as learning is the process of developing and supporting students' metacognition. Students are actively involved in assessments, by monitor students' learning, utilize feedback from teachers, from themselves and from peers to determine the next steps and set individual learning goals (Ministry of Education, 2010). There is almost no comparison between students with others (Earl, 2003). Assessment as learning requires teachers to switch from knowledge bearers to knowledge guides, namely to guide students through the process of understanding their "cognitive processes" so students learn to monitor their learning and make make adjustments (Rowe, 2012). In assessment as learning, students routinely reflect on their work and make decisions about how they can play a major role in what they have done (Earl, 2003). In more detail, Earl \& Katz (2006) stated that in assessment as learning, what is assessed is the mind of each student about learning, what strategies are used to support or enhance the learning, and the mechanism of students to make adjustments and help their learning.

Rowe (2012) proposed steps assessment as learning implementing namely 1) discuss the learning outcomes with the students, 2) create criteria with the students for the various tasks that need to be completed and/or skills that need to be learned or mastered, 3) provide feedback to students as they learn and ask them guiding questions to help them monitor their own learning, 4) help them set goals to extend or support their learning as needed in order to meet or fully meet the expectations, and 5) provide reference points and examples for the learning outcomes. WNCP (2012) was written method of assessment as learning implementing namely 1) introduce related learning outcomes, 2)

introduce rubric and modify criteria with students to fit curriculum expectations, 3) have students self-assess and peer-assess at intervals throughout a unit, 4) guide students through setting goals to improve, 5) provide feedback throughout the unit and ask guiding questions, 6) highlight examples throughout the unit of positive P.E. work habits as defined by the rubric, 7) finish unit with Assessment of Learning by teacher completion of the rubric. 
One of the impacts of applying assessment as learning was reported by Davies et al., (2011). According to them, the use of a wiki to emphasize the application of assessment as learning has enriched student learning experiences that can improve professional student outcomes. Quality student involvement, which is at general often a difficulty in classrooms, is made possible through the use of a simple but effective technology wiki. The wiki provides new opportunities for participants to compile their public practices and then work collaboratively and systematically to find and improve their assessment practices at Tertiary Educations.

A similar research results by Davies et al., (2011), in Singapore, elementary school students have self-assessing abilities, which is one of the important elements in assessment as learning, and when they learn self-assess more accurately and convincingly through practice, they can move on to learning how to learn and use information obtained through a self-assessment process to improve their learning (Wong, 2014).

Assessment as learning implementing makes studying more focus, more interesting and more productive, and instruction more focus on objective, more student centered and more effective (Lee \& Mak, 2009). Assessment as learning implementing also lead further development of cognition capacity and students' metacognition (Lam, 2015)

Thus, the theoretical and empirical basis of assessment as learning is good, but unfortunately it has not been balanced with the widespread application of as learning assessment. Education actors in several countries tend to perceive assessments within the framework of assessment of learning. There is little evidence that teachers in Exeter, the United States, actually use diagnostic or formative assessment strategies in planning and teaching (Radnor, 1996). Other evidence comes from the Group Reform Assessment report (2002) which indicated that in the United Kingdom, most class-based assessments refer to the paradigm of assessment of learning rather than assessment for learning. Whereas in Canada, Volante (2009) reported that elementary and junior high schools in Southern Ontario, Canada, only a small proportion used assessment as learning (student metacognition skills) and assessment for learning (formative) and most applied assessment of learning (summative).

The impact of assessment for learning implementing toward result of learning on a group have studied Stiggins \& Chappuis (2006), Glasson (2008), Hill (2008), Mehmood et al. (2012) and Wiliam (2013). These researches compare the impact of assessment for learning and assessment of learning toward result of learning. The impact of assessment as learning implementing toward result of learning on a group have studied Lee \& Mother (2009), Davies et al. (2011), Wong (2014) and Lam (2015). These researches compare the impact of assessment as learning and assessment of learning toward result of learning. This paper studied a group that it was given three kinds of treatment, namely assessment of learning, assessment for learning and assessment as learning implementations toward students' result of learning.

In this study, researchers will compare directly the impact of assessment of learning, assessment for learning and assessment as learning implementations toward result of 
learning on a group. The expectation was that the impact of assessment as learning is better than the impact of assessment for learning toward students' result, and the impact of assessment for learning is better than the impact of assessment of learning toward students' result.

\section{METHOD}

The subjects of research were 35 students of the 2015 Grade A Chemistry Education Study Program, semester 6 who were programming the Inorganic Chemistry III course. The research was conducted at the Even Semester of Academic Year 2017/2018 in the Chemistry Department, Mathematics and Natural Science Faculty of Surabaya State University, Indonesia. These subjects were chosen because they have programmed Assessment course, the class that easy to implement assessment of learning, assessment for learning and assessment as learning. The second reason, these subjects were programming the Inorganic Chemistry III course, which has low academic achievement at last many years. Thus those courses were chosen in order to increasing the result of learning. The focus of this research was only students' result of learning in the cognitive domain.

The design of this research is one-shot case study which is one type of pre-experimental research (Huck, 2008). In simple terms, the design was illustrated the diagram as follows:

\begin{tabular}{l} 
Students \\
\cline { 3 - 4 }
\end{tabular}
Explanation:
$\mathrm{X}_{1}=$ assessment of learning implementation (meeting 1-4)
$\mathrm{O}_{1}=$ paper test 1 after assessment of learning implementation (meeting 5)
$\mathrm{X}_{2}=$ assessment for learning implementation (meeting 6-9)
$\mathrm{O}_{2}=$ paper test 2 after assessment for learning implementation (meeting 10)
$\mathrm{X}_{3}=$ assessment as learning implementation (meeting 11-14)
$\mathrm{O}_{3}=$ paper test 3 after implementation assessment as learning (meeting 15)

Technique of data collecting used the result of learning test. The data supported by interview, observation of students' activity, book note, and worksheet. The main research instruments were the paper test 1,2 and 3 in order to measure result of learning 1, 2 and 3. Additional instruments were observation of students' activity, book note, and worksheet sheets that they were used to explain students activity in learning. Teaching administration were syllabus, lesson plan, worksheet and Guide Book. Steps of assessment for learning namely 1) clarifying learning intentions and criteria for success, 2) engineering effective classroom discussions and other learning tasks that elicit evidence of student understanding, 3) providing feedback that moves learners forward, 4) activating students as instructional resources for one another, 5) activating students as the owners of their learning Worksheet contains steps implementation assessment as learning which consists of 6 steps, such as 1) describing the strategies that have been used in learning; 2) describe the results of the SWOT analysis; 3) describe the target to 
be achieved regarding the final ability of a particular topic in the Inorganic Chemistry III course; 4) describe planning for improving learning with the help of Guide Book; 5) describe the questions and answers according to the final ability in the Inorganic Chemistry III course for a particular topic as a self-assessment or peer-assessment activity; and 6) describe questions and answers related to learn activities as selfassessment or peer assessment activities. The Guide book contains references in analyzing SWOT, reading techniques, memorization techniques, learning styles, time management, accurate tips on learning, concept maps and mind maps. If students searching this references by themself, it can take several days or more, since the source varies. Because of the presence of the Guide Book is expected can be very helpful in implementing assessment as learning.

Research instruments and teaching administration have been developed according to one of developing theory Four-D Model. The steps of Four-D Model were Define, Design, Develop, and Disseminate (Thiagarajan, et al., 1974). Properness of research instruments and learning material were viewed from validity, practically and effectiveness. Validity was determined by validator marking. Practically was determined students' response. Effectiveness was determined by the amount of students' mastery in learning.

Research instruments and learning equipment have been validated by Professor and lecturer of Graduate School, Malang State University, Indonesia and Professor of Graduate School, Surabaya State University, Indonesia. Mean of validity value of research instruments and learning equipment were 86.6 in very valid category. Reliability of paper test 1,2 and 3 were $0,786,0,69$, and 0,713 respectively in reliable category. Mean of students' response was $81.4 \%$ in very practice category. There were $75 \%$ students have been mastery in learning, in effective category. Thereby, research instruments and learning equipment were proper to be used.

The Learning Outcomes Inorganic Chemistry III course is mastering the existence, character and method to obtain the main group elements; use in according with its characteristics, have the responsibility to keep the environment and to apply it in solving science and technology problems in a simple scope through discussion, presentation, project assignments and delivery of oral or written ideas (Team, 2015). The description of Inorganic Chemistry III Course is a study of abundance, character, method to obtain, benefits and identify and be able to utilize the main group elements through discussion, presentation, project assignments, delivery of ideas both orally and in writing (Team, 2015). This course is taken in 15 meetings through the implementation of assessment of, for and as learning.

The main activities of learning in each implementation the type of assessment approach same in five meetings. First meeting lectures talk and questions and answers, one meeting held competition between groups answering the questions with clarification by lecturer if needed, The second meetings students are presentations the subject of study, completed by lecturer information if problem arises and another one meeting for paper test. But according to the approach, there are differences in additional activities that students or lecturers must do on the application of assessment of, for and as learning. 
The implementation assessment of learning was done at meeting 1-5. The activities at first meeting are lecture and question-and-answer sessions by lecturer with the subject matter of Group IA. The activities of $2^{\text {nd }}$ and $3^{\text {rd }}$ meeting are students' presentation of the subject matter of Group IIA added by lecturers' information if problems arise from student. The competition between groups to answers questions added with lecturer clarification if needed the Hydrogen subject matter held at the meeting 4. In the last meeting (meeting 5), paper test 1 was conducted by the researchers.

During the study observed by 3 observers. One person observes student activities and another two persons observe the quality of implementation learning by the lecturer. Among the $5^{\text {th }}$ and $6^{\text {th }}$ meetings were observations of student notebooks and interviews with students.

Result of paper test 1 and supporting data became reflection of material by the lecturer. The Reflection result is useful for lecturers to improve learning. The reflection process by lecturers is the main key for lecturers to implement the assessment for learning in order to improve learning.

The assessment for learning is held at meeting 6-10. Students presentation at $6^{\text {th }}$ and $7^{\text {th }}$ meetings with the subject matter of Group IIIA supported by lecturers' information if there are problems arises from student. The activities at meeting 8 is competitions between groups ton answer the questions confirmed with lecturer clarification if needed with the subject matter of Group IVA. Lecture and question- answer by lecturer with subject matter VA Group. Next, paper test 2 closed the implementation of assessment for learning at $10^{\text {th }}$ meeting.

Examples of reflections was made by lecturers are important lessons for students. Students get an idea how to analyze the weaknesses and strengths individual and choose suitable strategies for improving learning. This becomes an important for students to apply assessment as learning.

A week before the implementation of assessment as learning, students was given worksheet and Guide Book. The implementation of assessment as learning held at meetings 11-15. Students presentation at meeting 11 and 12 with subject matter of the VIA Group confirmed by lecturer information if there are problems. The activities at $13^{\text {th }}$ meeting are lectured and question-answer sessions by lecturers with subject matter of the VIIA Group. At meeting 14, the competition between groups to answer questions confirmed by lecturer clarification if needed with the subject matter of Group VIIIA. Next, paper test 3 closed the application of assessment as learning at meeting 15 .

Paper test 1, 2, and 3 results data are presented in one table. Based on the values in the table, it is then described in the form of grouping into categories A, A-, B +, B, B-, C +, $\mathrm{C}, \mathrm{D}$ and $\mathrm{E}$. The boundaries of the values are A (85-100), A- (80- 84.99), B + (7579.99), B (70-74.99), B- (65-69.99), C + (60-64.99), C (55-59.99), D (40-54.99) and E (0-39.99). The student was called mastery in learning if the student got score 55 (category C) or more. 
Result of paper test data is tested for normality using Shapiro-Wilk Test because amount of subject research is 35 that its' lower than 50 (Razali \& Wah, 2011). If normal data is known, then it is further tested whether there were differences paper test 1,2, and 3 using analysis of variant type repeated measures, but if normal data is not known, it is using Friedman (Huck, 2008) The paper test value is obtained in the following way:

Value $=\frac{\text { scare abtain }}{\text { maxscore }} \times 100$

\section{FINDINGS}

Result of paper test 1,2, and 3 were shown on Table 1 . Result of paper test 1, 2, and 3 represented if normal data is known implementation of assessment of learning, assessment for learning and assessment as learning respectively. Value range was 1-100.

If data in Table 1 was classified into A, A-, B+, B, B-, C+, C, D, and E category in percentage so the its result was shown in Table 2. There was increasing in result of learning from paper test 1 to paper test 2 and to paper test 3, mainly higher value as $\mathrm{A}$, $\mathrm{A}-$, and $\mathrm{B}^{+}$. The vice versa, there was decreasing in result of learning, mainly lower value as $\mathrm{B}, \mathrm{B}^{-}, \mathrm{C}^{+}, \mathrm{C}, \mathrm{D}$, and $\mathrm{E}$.

Table 1

Students' Value in Paper Test 1, 2, and 3

\begin{tabular}{|c|c|c|c|c|c|c|c|c|c|}
\hline \multirow{2}{*}{ No. } & \multirow{2}{*}{$\begin{array}{l}\text { Students' } \\
\text { Name }\end{array}$} & \multicolumn{3}{|c|}{ Paper Test } & \multirow{2}{*}{ No. } & \multirow{2}{*}{$\begin{array}{l}\text { Students' } \\
\text { Name }\end{array}$} & \multicolumn{3}{|c|}{ Paper Test } \\
\hline & & 1 & 2 & 3 & & & 1 & 2 & 3 \\
\hline 1 & PIKM & 45.8 & 86.4 & 91.7 & 19 & ST & 66.7 & 90.9 & 83.3 \\
\hline 2 & RTA & 37.5 & 72.7 & 75.0 & 20 & S & 45.8 & 81.8 & 83.3 \\
\hline 3 & MFSK & 37.5 & 86.4 & 87.5 & 21 & RKN & 45.8 & 95.5 & 91.7 \\
\hline 4 & MSR & 50.0 & 50.0 & 58.3 & 22 & $\mathrm{AFN}$ & 58.3 & 68.2 & 91.7 \\
\hline 5 & RED & 62.5 & 100.0 & 87.5 & 23 & EAP & 58.3 & 77.3 & 66.7 \\
\hline 6 & BBM & 41.7 & 81.8 & 87.5 & 24 & RA & 54.2 & 86.4 & 95.8 \\
\hline 7 & FRS & 54.2 & 90.9 & 79.2 & 25 & CYS & 25.0 & 63.6 & 50.0 \\
\hline 8 & MDAR & 20.8 & 63.6 & 83.3 & 26 & UNH & 37.5 & 100.0 & 87.5 \\
\hline 9 & FA & 54.2 & 81.8 & 100.0 & 27 & LSP & 45.8 & 90.9 & 79.2 \\
\hline 10 & BSYS & 45.8 & 68.2 & 87.5 & 28 & AR & 54.2 & 81.8 & 87.5 \\
\hline 11 & KTR & 58.3 & 90.9 & 91.7 & 29 & DW & 50.0 & 81.8 & 83.3 \\
\hline 12 & $\mathrm{ZS}$ & 58.3 & 81.8 & 87.5 & 30 & RAJ & 29.2 & 63.6 & 66.7 \\
\hline 13 & HW & 50.0 & 77.3 & 95.8 & 31 & AWS & 50.0 & 77.3 & 75.0 \\
\hline 14 & VAS & 50.0 & 68.2 & 79.2 & 32 & SNAA & 29.2 & 81.8 & 75.0 \\
\hline 15 & SPA & 66.7 & 86.4 & 100.0 & 33 & $\mathrm{ARF}$ & 41.7 & 63.6 & 75.0 \\
\hline 16 & MM & 37.5 & 81.8 & 58.3 & 34 & BEP & 37.5 & 77.3 & 58.3 \\
\hline 17 & MFR & 50.0 & 63.6 & 83.3 & 35 & FDN & 54.2 & 77.3 & 83.3 \\
\hline 18 & $\mathrm{RK}$ & 50.0 & 77.3 & 91.7 & Aver & & 47.3 & 79,1 & 81,7 \\
\hline
\end{tabular}

Passing grade to be mastery in learning was value C. Based on Table 2, only $20 \%$ students were mastery in learning through assessment of learning implementation. Mastery in learning at assessment for and as learning implementations were $97.1 \%$ and $97.1 \%$ respectively. The fact showed that result of learning through assessment as learning implementation better than assessment for learning implementation. The same way result of learning through assessment for learning implementation better than assessment of learning implementation. 
Table 2

Distribution Value on Paper Test 1,2, and 3 in Percentage

\begin{tabular}{|c|c|c|c|c|c|c|c|c|c|c|}
\hline \multirow{4}{*}{$\begin{array}{l}\text { Paper } \\
\text { test }\end{array}$} & \multicolumn{9}{|c|}{ Percentage (\%) student that they got value } & \multirow{4}{*}{ Totally } \\
\hline & A & A- & $\mathrm{B}+$ & $\mathrm{B}$ & B- & $\mathrm{C}+$ & $\mathrm{C}$ & $\mathrm{D}$ & $\mathrm{E}$ & \\
\hline & $85-$ & $80-$ & $75-$ & $70-$ & $65-$ & $60-$ & $55-$ & $40-$ & $0-$ & \\
\hline & 100 & 84.9 & 79.9 & 74.9 & 69.9 & 64.9 & 59.9 & 54.9 & 39.9 & \\
\hline 1 & 0 & 0 & 0 & 5.7 & 0 & 2.9 & 11.4 & 54.3 & 25.7 & 100 \\
\hline 2 & 31.4 & 20 & 17.1 & 5.7 & 8.6 & 14.3 & 0 & 2.9 & 0 & 100 \\
\hline 3 & 48.6 & 14.2 & 20 & 0 & 5.7 & 0 & 8.6 & 2.9 & 0 & 100 \\
\hline
\end{tabular}

The different of implementing assessment of learning, assessment for learning, and assessment as learning toward result of learning is or not significant, it was tested using analysis of variant type repeated measures for normal distribution data. If distribution data was not normal, it was used Friedman test. Result of normality test used Shapiro Wilk test was shown in Table 3. Table 3 showed that data of paper test 1 and 2 were normal distribution, because numeral of sig. column were higher than 0.05 , but data of paper test 3 was not normal distribution because numeral of sig. column was lower than 0.05. Therefore, testing of the different implementing assessment of learning, assessment for learning, and assessment as learning toward result of learning used Friedman test.

Table 3

Result of Normality Test used Shapiro Wilk Test for Result of Learning 1, 2, and 3

\begin{tabular}{llll}
\hline \multirow{2}{*}{ Data } & \multicolumn{3}{l}{ Shapiro-Wilk } \\
\cline { 2 - 4 } & Statistic & df & Sig. \\
\hline Paper test 1 & .962 & 35 & .270 \\
Paper test 2 & .960 & 35 & .229 \\
Paper test 3 & .919 & 35 & .013 \\
\hline
\end{tabular}

Asymp. Sig. column at the Table 4 showed number 0.000 . This numeral was lower than 0.05. It means, there was the significant different of implementing assessment of learning, assessment for learning, and assessment as learning toward result of learning.

Table 4

Result of Testing the Different of Learning Result 1, 2, and 3 used Friedman Test

\begin{tabular}{ll}
\hline $\mathrm{N}$ & 35 \\
\hline Chi-Square & 53.281 \\
df & 2 \\
Asymp. Sig. & .000 \\
\hline
\end{tabular}

\section{DISCUSSION}

At the assessment of learning implementation do not need involvement of student (Funk, 2009). Lecturer become key assessor in learning when applied assessment of learning (Earl, 2003). Result of interview and observation of students' activity, and inspection of students' notebook indicated that more student behave passive in learning. They did not plan goals that it will be reached in learning. They did not conduct planning of goals. 
They did not conduct reflection to what have or not yet been known, what have or not yet been done related their learning. So, lecturer did not conducted reflection toward process and result of learning as step improved learning. Assessment is a process of information collection, and in the context of teaching, this information is typically used to examine and described student performance (Enger \& Yager, 2009). Student did not involve and not yet conducted of reflection by lecturer become one of reason that lower of learning result from assessment of learning implementation. Percentage of student amount that they got value A; A-; B+; B; B-; C+; C; D; and E by successively were $0 \%$; $0 \% ; 0 \% ; 5.7 \% ; 0 \% ; 2,9 \% ; 11,4 \% ; 54,3 \%$; and $25.7 \%$. The student was called mastery in learning if they got value $\mathrm{C}$ or more. Thereby, only $20 \%$ student which mastery in learning at assessment of learning implementation (Table 2).

Result of assessment of learning implementation become feedback material for lecturer improved next learning. Learning feedback, mainly by lecturer became key conducted assessment for learning (Earl, 2003). Assessment for learning implementation need involvement of student because students were someone which the most able improved its learning (Funk, 2009). Based on result of paper test 1, indicated that student majority cannot answer the question in analysis category. For example, 'Why is hydrogen element not suitable put down in Group IA?". Based on this analysis, lecturer give some clarification that is informed toward student to strengthen ability of its analysis. Lecturer also urge toward student to analysis to its own learning. For example, student analysed their strong and weakness, learning strategy which during the time they used, have been effective or not, and also how the students' time management. So, before students conduct the presentation in 6th and 7th meeting, lecturer remind the student to discuss the utility of element or its compound of Group IIIA, shall be related to the nature of compound or element. When there was question which will be raised, student may be direct enquire without waiting presentation finished, so presentation was not boring. Many questions have made for competition among group have to include abundant, extraction, utility of element and its compounds that it was commended in syllabus of Inorganic Chemistry III. This action was conducted because at competition among the previous group, questions have been made not yet representation of all material in syllabus.

Learning feedback by lecturer and involving of student in learning during assessment for learning implementation caused the increasing of students' achievement. Formative assessments and feedback provide an important opportunity to support and enhance student learning (Spector, et. al. 2016). Assessment for learning was a range of informal and formal procedure which teacher was done as part of normal processes in teaching and learning which its information was used to modify and improve learning and understanding (Black \& Wiliam, 2001). Its result, 97.1\% student's mastery in learning (Table 2). Statistically, mean of students' result of learning at assessment for learning implementation were higher than mean of students' result of learning at assessment of learning implementation (Table 1). Result of Friedman test also showed students' result of learning at assessment for learning and assessment of learning implementations were different significantly (Table 4). This fact, suitable according to the research finding of 
some researchers that assessment for learning can improve students' achievement (Stiggins \& Chappuis, 2006; Glasson, 2008; Mehmood, at al., 2012; and Wiliam, 2013).

Students' experiences to improve their learning as it was taught lecturer, at assessment for learning implementation became necessary material for student to realize assessment as learning in learning. If lecturer became key assessor at assessment of learning and assessment for learning, hence student became key assessor at assessment as learning (Earl, 2003). During assessment as learning implementation, student given students' worksheet and Guide Book. Result of analysis students' worksheet showed majority of students conducted steps of assessment as learning. Group of WhatsApp (WA) is also formed to facilitate communications and peer assessment. Steps of Assessment as learning were conducted outside class learning. Student have done 1) describing the strategies that have been used in learning; 2) describe the results of the SWOT analysis; 3 ) describe the target to be achieved regarding the final ability of a particular topic in the Inorganic Chemistry III course; 4) describe planning for improving learning with the help of Guide Book; 5) describe the questions and answers according to the final ability in the Inorganic Chemistry III course for a particular topic as a self-assessment or peerassessment activity; and 6) describe questions and answers related to learn activities as self-assessment or peer assessment activities.

Students' worksheet contains three main topics that is Group VIA, VIIA and VIIIA. Experience and process of learning in every meeting was made for students ever monitored its learning activity, conducted adjustments immediately, in order improved their result of learning. Assessment as learning can improve to the skill and ability, especially in the peer review where they mutually engaged with each other in a coordinated effort to raise questions and solve problems together (Gong, et.al., 2018). Accuracy and consistence of self-reflection, self-monitoring and self-adjustment became quality insurance of assessment as learning implementation (Earl, 2003). The fact showed that enhance students' result of learning through assessment as learning implementation.

Based on result of analysis paper test 3 as representation assessment as learning implementation, it was seen that $97,1 \%$ students mastery in learning (Tables 2). Based on the Table 2, it was seen that $97,1 \%$ students mastery in learning at assessment as learning and also at assessment for learning implementation. This conditions can be happened because they same in many term theoretically. Both assessment for and as learning implementations need involvement student, determined purpose of learning, need feedback from teacher (Earl, 2003; Rowe, 2012), formative in term, not compare student with another student, and describe the achievement instead of score in report (Earl, 2003; Earl \& Katz, 2006; Ministry of Education, 2010).

But it was reviewed percentage of student amount for result of learning through assessment for and as learning implementations, it was happened increasing value. Percentage of students amount for result of learning through assessment for and as learning implementations successively for value A were $31.4 \%$ and $48.6 \%$; value $\mathrm{B}+$ were $17.1 \%$ and $20 \%$, value $\mathrm{C}+$ were $14.3 \%$ and $0 \%$; value $\mathrm{D}$ were $2.9 \%$ and $2.9 \%$; and value $\mathrm{E}$ were $0 \%$ and $0 \%$. There were increasing at many higher values as $\mathrm{A}$ and $\mathrm{B}+$, 
there was decreasing lower value as $\mathrm{C}$, and there were permanent in many values. This fact indicated that result of learning through assessment as learning better than assessment for learning implementations. Result of learning through assessment for learning better than assessment of learning implementations.

Statistically, mean of students' result of learning at assessment as learning was higher than mean of students' result of learning at assessment of learning and also at assessment for learning implementations (Table 1). Result of Friedman test also showed that there was the significant different of implementing assessment of learning, assessment for learning, and assessment as learning toward result of learning (Table 4). This fact suitable with findings some researchers that applying assessment as learning can improve students' result of learning (Lee \& Mak, 2009; Davies, at al., 2011; Berry, 2013; Wong, 2014; and Lam, 2015).

\section{CONCLUSION}

Based on findings and discussion above can be concluded:

1. Percentage of students amount for result of learning through assessment of, for and as learning implementation successively for value $\mathrm{A}$ were $0 \% ; 31.4 \%$ and $48.6 \%$; value $\mathrm{A}^{-}$were $0 \% ; 20 \%$ and $14.2 \%$; value $\mathrm{B}^{+}$were $0 \% ; 17.1 \%$ and $20 \%$; value $\mathrm{B}$ were $5.7 \% ; 5.7 \%$ and $0 \%$; value $\mathrm{B}^{-}$were $0 \% ; 8.6 \%$ and $5.7 \%$; value $\mathrm{C}+$ were $2.9 \%$; $14.3 \%$ and $0 \%$; value $\mathrm{C}$ were $11.4 \% ; 0 \%$ and $8.6 \%$; value $\mathrm{D}$ were $54.3 \% ; 2.9 \%$ and $2.9 \%$; and value $\mathrm{E}$ were $25.7 \%$; $0 \%$ and $0 \%$.

2. Percentage of students amount that its mastery in learning through were assessment of, for and as learning implementation were $20 \%$; $97.1 \%$ and $97.1 \%$ respectively.

3. Means' result of learning through assessment of, for and as learning implementation successively 47,3; 79,1; and 81,7.

4. Students' result of learning through assessment of learning, assessment for learning, and assessment as learning implementations were different significantly based on Spearman test.

Thus, students' result of learning through assessment as learning implementation was better than assessment for learning implementation, and students' result of learning through assessment for learning implementation was better than assessment of learning implementation.

\section{SUGGESTION}

This research studied students' result of learning on cognitive domain only, it was suggested to concern on affective and psychomotor domain.

\section{REFERENCES}

Assessment Reform Group. (2002). Assessment for learning: Research-based principle to guide classroom practice. Cambridge, UK: Assessment reform group.

Berry, R. (2013). The assessment as learning (AAL) framework for teaching and learning-the AAL wheel. Assessment and Learning, 2, 53-70. 
Black, P., \& William, D. (2001). Inside the black box: Raising standards through classroom assessment. King's College London School of Education.

Davies, A., Pantzopoulos, K., \& Gray, K. (2011). Emphasizing assessment as learning by assessing wiki writing assignments collaboratively and publicly online. Australasian Journal of Educational Technology, 27(5), 798-812.

Earl, L. (2003). Assessment as learning: Using classroom assessment to maximize student learning. Thousand Oaks, United State: Corwin Press Inc.

Earl, K., \& Giles, D. (2011). An-other look at assessment: Assessment in learning. New Zealand Journal of Teachers' Work, 8(1), 11-20.

Earl, L., \& Katz, S. (2006). Rethinking classroom assessment with purpose in mind. Assessment for learning, assessment as learning, assessment of learning. Retrieved from http://www.wncp.ca/media/40539/rethink.pdf.

Enger, S. K., \& Yager, R. E. (2009). Assessing student understanding in science. Thousand Oaks, United State: Corwin Press Inc.

Funk, B. (2009). Assessment for learning. Retrieved from www.etec.ctlt.ubc.ca/510wiki/Assessment_for_Learning.

Glasson, T. (2008). Improving student achievement through Assessment for Learning. Curriculum \& Leadership Journal, 6(31).

Gong, C, Chin, C. K., \& Tan, C. L. (2018). Scaffolding instruction of Chinese essay writing with assessment as learning. In K. C. Soh (Ed.), Teaching Chinese language in Singapore (pp.121-134). Springer.

Heitink, M. C., Van der Kleijb, F. M., Veldkampa, B. P., Schildkampa, K., Kippersa, W. B. (2016). A systematic review of prerequisites for implementing assessment for learning in classroom practice. Educational Research Review, 17, 50-62

Hill, M. (2008). Using classroom assessment for effective learning-tension and energies. The Curriculum Journal, 16(2).

Huck, S. W. (2008). Reading statistics and research. New York: Harper \& Row.

Kulasegaram, K. M., \& Rangachari, P. K. (2018). Best practices beyond "formative": assessments to enrich student learning. Adv Physiol Educ, 42, 5-14.

Lam, R. (2015). Assessment as learning: Examining a cycle of teaching, learning, and assessment of writing in the portfolio-based classroom. Studies in Higher Education, 41(11), 1900-1917. https://doi.org/10.1080/03075079.2014.999317.

Lee, I \& Mak, P. (2009). Assessment as learning in the language classroom. Assessment and Learning, 3, 66-78.

Mehmood, T., Hussein, T., Khalid, M., \& Azam, R. (2012). Impact of formative assessment on academic achievement of secondary school student. International Journal of Business and Social Science, 3(17), 101-104. 
Ministry of Education. (2010). Growing success: Assessment, evaluation and reporting in Ontario school. Retrieved from http://www.edu.gov.on.ca.

O'Farrell, C. (2009). Enhancing student learning through assessment. Dublin Institute of Technology. Retrieved from http://www.assessmenttoolkit.pdf.

Radnor, H. (1996). Evaluation of key stage 3 assessment in 1995 and 1996. London: School Curriculum and Assessment Authority.

Razali, N. M., \& Wah, Y. B. (2011). Power comparison of Shapiro-Wilk, KolmogorovSmirnov, Lilliefors, And Anderson-Darling Test. Journal of Statistical Modelling and Analytics, 2(1), 21-23.

Rowe, J. (2012). Assessment as learning-ETEC 510. Retrieved from www.etec.ubc.ca/510wiki/Assessment_as_Learning\#Assessment_for_Learning.

Spector, J. M., Ifenthaler, D., Samspon, D., Yang, L., Mukama, E., Warusavitarana, A., Lokuge Dona, K., Eichhorn, K., Fluck, A., Huang, R., Bridges, S., Lu, J., Ren, Y., Gui, X., Deneen, C. C., San Diego, J., \& Gibson, D. C. (2016). Technology enhanced formative assessment for 21 st century learning. Educational Technology \& Society, $19(3), 5$

Stiggins, R., \& Chappuis, J. (2006). What a difference a word makes: assessment for learning rather than assessment of learning helps students succeed. JSD, 27(1), 10-14.

Team. (2014). The impact of formative assessment and learning intention on student achievement. Retrieved from www.hanoverresearch.com.

Thiagarajan, S., Semmel, D. S., \& Semmel, M. I. (1974). Instructional development of training teachers of exceptional children: A sourcebook. Indiana: Indiana University.

Team. (2015). Guide book of Surabaya state university for generation 2015. Surabaya, Indonesia: University press.

Ussher, B., \& Earl, K. (2010). Summative and formative: Confused by the assessment terms? New Zealand Journal of Teachers' Work, 7(1), 53-63.

Volante, L. (2009). Assessment of, for, and as learning within schools: Implication for transforming classroom practice. Action in Teacher Education, 31(4), 66-75.

Wiliam, D. (2013). Assessment: The bridge between teaching and learning. Voice from the Middle, 21(2), 15-20.

Western \& Northern Canadian Protocol (WNCP). (2006). Rethinking classroom assessment: assessment for learning, assessment as learning, assessment of learning. Retrieved from http://www.edu.gov.mb.ca/k12/assess/wncp/rethinking_assess_mb.pdf.

Wong, H. M. (2014). I can assess myself: Singaporean primary students' and teachers' perception of students' self-assessment ability. Education, 3-13, 44(4), 442-457. doi: 10.1080/03004279.2014.982672. 